\title{
Pendidikan Karakter Anak Usia Dini Melalui Mainan Edukatif Amigurumi Berbasis Budaya Lokal
}

\section{Early Childhood Character Education Through Amigurumi Educational Toys Based on Local Culture}

\author{
Ni Wayan Satiani Pradnya Paramita \\ Magister Keguruan Seni Rupa, Fakultas Sastra, Universitas Negeri Malang, Indonesia
}

\begin{abstract}
Abstrak
Pendidikan karakter perlu untuk diberikan sedini mungkin pada anak-anak. Mainan edukatif sebagai alat pendukung edukasi dapat menjadi media pendidikan karakter, namun masih jarang ditemukan mainan edukatif yang wujud visualnya memiliki nilai budaya lokal. Kebanyakan dari mainan edukatif tersebut mengacu pada mainan populer yang berkiblat pada budaya Barat. Kondisi tersebut perlu diimbangi dengan penciptaan mainan-mainan edukatif yang memiliki ciri budaya lokal sebagai bentuk pengenalan anak usia dini pada budayanya sekaligus menjadi media bagi pendidik untuk menginternalisasikan pendidikan karakter. Proses penciptaan mainan edukatif dalam tulisan ini menggunakan langkah-langkah metodologis yang diuraikan secara deskriptif kualitatif yang dimulai dari pengumpulan data, analisis data, dan proses perwujudan. Dalam tulisan ini akan diuraikan proses penciptaan mainan edukatif berupa amigurumi dengan tema Ramayana yang diwakili oleh tokoh Rama dan Sinta yang ide visualnya bersumber pada lukisan wayang gaya Kamasan serta analisis kegunaannya bagi pendidikan karakter anak usia dini. Manfaat penggunaan boneka amigurumi Rama dan Sinta dalam pembelajaran antara lain: sebagai salah satu upaya literasi visual budaya lokal bagi anak usia dini dan sebagai media penyampaian nilai-nilai pendidikan karakter yang menarik serta tidak membosankan.
\end{abstract}

Kata Kunci: Mainan Edukatif; Pendidikan Karakter; Anak Usia Dini; Budaya Lokal

\begin{abstract}
Character building needs to be given as early as possible. Educational toys can be a medium for character building, but it is still rare to find educational toys that have local cultural values. Most of these educational toys refer to popular toys that are oriented towards Western culture. This condition needs to be balanced with the creation of educational toys that have local cultural characteristics as a form of early childhood introduction to their culture as well as a medium for educators to internalize character building. The process of creating educational toys in this paper uses methodological steps that are described in a descriptive qualitative way, starting from data collection, data analysis, and the embodiment process. In this paper, will be described the process of creating educational toys in the form of amigurumi with the theme of Ramayana, represented by the characters Rama and Sinta which visual ideas are based on Kamasan-style puppet paintings and an analysis of their use for early childhood character building. The benefits of using Rama and Sinta amigurumi dolls in learning are: as a visual literacy of local culture for early childhood and as an interesting medium for conveying character building values.

Keywords: Educational Toys; Character Building; Early Childhood; Local Culture
\end{abstract}

How to Cite: Paramita, N.W. (2021), Pendidikan Karakter Anak Usia Dini Melalui Mainan Edukatif Amigurumi Berbasis Budaya Lokal, Jurnal Pendidikan dan Penciptaan Seni, 1(2) 2021: 68-77,

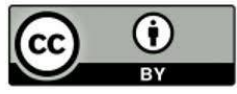




\section{PENDAHULUAN}

Pendidikan di era global saat ini tidak hanya berfungsi sebagai transfer pengetahuan (transfer of knowledge), namun juga berfungsi penting dalam membangun pondasi nilainilai bagi peserta didik. Pesatnya perkembangan teknologi dengan berbagai kemudahan dalam mendapatkan informasi dan kebiasaan menggunakan gawai sejak dini, menyebabkan pengaruh budaya visual dari berbagai negara terhadap perkembangan anak menjadi sebuah keniscayaan. Tentunya tidak semua dari pengaruh tersebut memberi dampak yang baik bagi perkembangan karakter anak. Apabila anak tidak memiliki landasan budaya yang luhur, akan berpotensi terhanyut dalam arus budaya global yang negatif. Maka, hendaknya nilai-nilai pendidikan karakter mulai dikenalkan pada anak sedini mungkin. Pendidikan karakter mengacu pada pembentukan watak dan kepribadian. Berdasarkan pendapat Ratna Megawangi, pendidikan karakter merupakan suatu usaha mendidik anak-anak agar dapat mengambil keputusan secara bijaksana dalam kehidupan sehari-hari (Wantu, 2020). Di samping itu, pendidikan karakter dapat dimaknai sebagai upaya untuk mendorong anak-anak untuk tumbuh dengan mengembangkan kompetensi berpikir, berpegang teguh pada prinsip-prinsip moral, memiliki keberanian dalam melakukan hal yang benar (Wigunadika, 2018). Pentingnya pendidikan karakter didukung oleh program Penguatan Pendidikan Karakter (PPK) oleh pemerintah yang terintegrasi dengan Gerakan Nasional Revolusi Mental, yang berfokus pada perubahan cara berpikir, bersikap, dan bertindak agar menjadi lebih baik (Azwar, 2017). PPK tertuang dalam Rencana Pembangunan Jangka Panjang Nasional (RJPN) tahun 2005-2025 dimana pendidikan karakter menjadi landasan untuk mewujudkan visi pembangunan nasional dalam mewujudkan masyarakat yang berakhlak mulia, bermoral, beretika, berbudaya, dan beradab berdasarkan Pancasila (Kemendiknas, 2011).

Pendidikan anak usia dini tidak hanya mendidik anak agar cerdas secara akademik, tetapi juga untuk membentuk kepribadian dan karakter. Sebagaimana yang diungkapkan oleh Ki Hadjar Dewantara bahwa pendidikan merupakan proses pembudayaan, yakni suatu upaya dalam membekali nilai-nilai luhur kepada generasi selanjutnya yang bersifat memelihara, memajukan, dan mengembangkan kebudayaan menuju arah yang lebih baik (Mudana, 2019). Pandangan Ki Hajar Dewantara mengenai pendidikan karakter antara lain: 1) pendidikan karakter adalah bagian yang tidak terpisahkan dalam sisitem pendidikan nasional; 2) pendidikan karakter membentuk mental atau sikap yang baik (sikap jujur, disiplin, bertanggung jawab, demokratis, tidak mementingkan diri sendiri, berani, rela berkorban, tidak merusak, tidak menyakiti orang lain, hidup sehat dan bersih, hormat kepada orang tua, toleran, empati dan cinta tanah air); 3) pendidikan karakter bagi anak usia dini dapat dilakukan terutama oleh orang tua dan guru melalui pembiasaan dalam berbagai kegiatan pembelajaran melalui bercerita, mengambar, bermain dengan alat permaian tradisional, menyulam, beryanyi (Iswantiningtyas \& Wulansari, 2018). Lebih lanjut, pendidikan karakter yang baik berdasarkan pendapat Thomas Lickona (1991) harus melibatkan pengetahuan yang baik (moral knowing), perasaan yang baik (moral feeling) dan perilaku yang baik (moral action) sehingga terbentuk perwujudan kesatuan perilaku dan sikap hidup peserta didik (Muchtar \& Suryani, 2019). Berdasarkan uraian tersebut, pendidikan karakter membutuhkan proses yang berkelanjutan dan tidak instan. Dibutuhkan waktu untuk menanamkan pengetahuan mengenai moral yang baik dan menumbuhkan perasaan yang baik untuk dapat membiasakan perilaku yang baik. Sehingga, pendidikan karakter seyogyanya dilaksanakan sedini mungkin.

Anak usia dini berdasarkan Undang-Undang Republik Indonesia Nomor 20 Tahun 2003 adalah kelompok individu yang berusia 0-6 tahun. Dalam rentang usia tersebut, anak sedang berada dalam tahap yang sangat krusial dalam pembentukan kepribadian dan 
pengembangan kecerdasannya. Sebab pada masa ini merupakan masa awal anak-anak mengembangkan kemampuan fisik, kognitif, bahasa, sosial emosional, konsep diri, disiplin, kemandirian, seni moral, dan nilai-nilai agama (Kurniawan, et.al., 2020). Pendidikan karakter bagi anak usia dini sebaiknya menggunakan pendekatan-pendekatan yang sesuai dengan perkembangan mereka. Salah satunya adalah melalui mainan edukatif. Bermain adalah kegiatan utama yang mulai nampak sejak bayi berusia 3 sampai 4 bulan. Kegiatan ini penting bagi perkembangan, kognitif, sosial dan kepribadian, serta emosional anak (Pramono, 2012). Mainan edukatif yang dibutuhkan anak adalah mainan yang aman, nyaman saat dimainkan, dan memiliki sifat yang menyenangkan serta dapat mengedukasi anak-anak dalam proses bermainnya.

Mainan edukatif dapat menjadi media pendidikan karakter, namun masih jarang ditemukan mainan edukatif yang wujud visualnya memiliki nilai budaya lokal. Kebanyakan dari mainan edukatif tersebut tidak memiliki nilai budaya lokal dan mengacu pada mainan populer yang berkiblat pada budaya Barat. Kondisi tersebut perlu diimbangi dengan penciptaan mainan-mainan edukatif yang memiliki ciri budaya lokal sebagai bentuk pengenalan anak usia dini pada budayanya sekaligus menjadi media bagi pendidik untuk menginternalisasikan pendidikan karakter. Untuk itu, dibutuhkan suatu media atau sarana yang memiliki nilai budaya lokal namun tampilannya kekinian dan sesuai dengan selera anak-anak, salah satunya adalah boneka rajut atau yang disebut dengan istilah amigurumi.

Salah satu budaya lokal yang masih relevan hingga kini adalah kisah Ramayana. Ramayana merupakan cerita legendaris yang berasal dari India yang dari masa ke masa terus hidup dan berkembang di Indonesia. Di Bali, kisah Rama dan Sinta kerap menjadi sumber inspirasi penciptaan seni lukis wayang Kamasan, akar dari gaya seni lukis klasik yang pertama di Bali. Gaya seni lukis tersebut berkembang dari daerah Klungkung sejak masa Raja Dalem Waturenggong (abad 14-15 masehi). Lukisan gaya Kamasan berasal dari perkembangan wayang kulit sebab dapat dilihat dari ciri-ciri teknik pembuatan, pakem bentuk, dan penampilan wajah tokohnya tidak jauh berbeda (Suartha, 1993 dalam Parta, 2015). Pengaruh karakter tokoh Rama dan Sinta pun begitu besar dalam berbagai aspek seni budaya yang hingga saat ini pengaruhnya masih tetap ada. Kisah tersebut sarat akan nilai-nilai filosofis dan nilai moral. Dalam tulisan ini, penulis menguraikan proses kreatif penciptaan transformasi tokoh Rama dan Sinta gaya Kamasan ke dalam mainan edukatif amigurumi sebagai sarana untuk pendidikan karakter bagi anak usia dini. Kemudian, analisis mengenai fungsi dan manfaat mainan edukatif tersebut juga akan disajikan dalam tulisan ini.

\section{METODE PENELITIAN}

Proses penciptaan mainan edukatif dalam tulisan ini menggunakan langkah-langkah metodologis yang dimulai dari pengumpulan data, analisis data, dan proses perwujudan. Pengumpulan data menggunakan studi pustaka dengan kerangka teori pendidikan karakter dan mainan edukatif anak usia dini. Analisis data menggunakan teori formalisme dan proses perancangan mainan edukatif menggunakan teori penciptaan. Teori formalisme menurut Adams (1996) dalam Rohidi (2011) merupakan suatu pendekatan tentang seni yang menekankan pada pentingnya bentuk sebagai sumber daya tarik subjektif suatu karya. Kesan-kesan yang ditimbulkan oleh unsur-unsur formal akan dipertimbangkan dalam proses perancangan. Analisis formal tersebut harus mempertimbangkan bagaimana setiap unsur menyumbang secara fungsional pada keseluruhan kesan yang ditimbulkan pada karya tersebut. Data yang diperoleh digunakan untuk menganalisis mengenai: (a) proses perancangan desain Rama dan Sinta dengan 
sumber visual gaya Kamasan sebagai ide penciptaan mainan edukatif amigurumi untuk anak usia dini dan (b) manfaat mainan edukatif amigurumi Rama dan Sinta dalam pendidikan karakter Anak Usia Dini.

\section{HASIL DAN PEMBAHASAN \\ Ide Visual Mainan Edukatif Berbasis Budaya Lokal}

Kisah Ramayana telah menjadi media pembelajaran spiritual sejak masa kerajaan Hindu di Jawa dan Bali yang menekankan moral sosial melalui pengajaran mengenai pentingnya kepatuhan pada hukum moral (Pujiyanto et al., 2021). Kisah tersebut sering menjadi tema lukisan klasik Kamasan. Seni lukis wayang Kamasan memiliki nilai sejarah dan nilai budaya lokal Nusantara sebab seni lukis ini telah berkembang sejak masa Majapahit. Perkembangan seni lukis wayang tersebut berpusat di daerah Kamasan, Klungkung dengan tema umumnya mengenai kisah-kisah yang bersumber pada kitab suci seperti Ramayana dan Mahabarata. Fokus dari lukisan tersebut terutama episode yang membawakan pesan-pesan orang suci, keberanian, kekuatan, peperangan, pembaktian diri dan kebijaksanaan (Parta, 2011). Fungsi dari seni lukis pada waktu itu terutama untuk kepentingan adat, pura, dan puri (kerajaan). Karya-karya yang ditampilkan merupakan ilustrasi naratif baik cerita maupun ikonografinya diturunkan langsung dari kesenian wayang. Kebudayaan tradisional yang bersifat kolektif di Bali menghasilkan karya-karya seni rupa yang bersifat simbolis dan bernilai sakral. Sebagaimana budaya visual Indonesia dapat dipahami sebagai hasil pemikiran holistik antara dimensi antropologis (nilai kemanusiaan), dimensi kosmologis (nilai-nilai keteraturan harmonis, kosmis/universal), dan dimensi teologis, dimana kebudayaan tersebut kini diolah kembali menyesuaikan perkembangan zaman (Djatiprambudi, 2019).

Gaya lukis wayang Kamasan ditransformasikan ke dalam berbagai media selain kanvas seperti caping, tas, keben, kipas, dan aksesoris lainnya yang menjadi cindera mata memiliki nilai jual yang membantu perekonomian masyarakat. Namun, masih belum banyak ditemukan mainan edukatif yang idenya bersumber dari lukisan Kamasan tersebut. Nilai-nilai luhur yang ada dalam kisah Ramayana perlu untuk disampaikan melalui media baru yang dekat dengan anak-anak. Dalam hal ini, nilai-nilai moral dan ciri budaya lokal dapat divisualkan dalam mainan edukatif sehingga anak-anak dapat belajar mengenai baik dan buruk serta memahami dampak dari perbuatan tersebut. Dari sanalah ide penciptaan amigurumi dengan sumber visual gaya Kamasan ini muncul.

\section{Proses Perwujudan Mainan Edukatif Amigurumi Rama dan Sinta}

Mainan edukatif yang ditujukan untuk anak usia dini sebaiknya dapat membawa suasana yang ceria dan merangsang anak untuk memainkannya, misalnya dengan menggunakan warna-warna yang cerah, sebab warna dapat memberikan rangsangan tersendiri yang berpengaruh positif terhadap perkembangan otak dan fungsi indera anakanak. Fungsi mainan bagi anak-anak bukan hanya sebagai media bermain namun juga berperan serta dalam proses belajar anak dalam mengembangkan pengetahuan yang lebih luas. Di samping itu, faktor keamanan dan kenyamanan mainan anak menjadi faktor penting dalam suatu perancangan mainan anak, mulai dari bahan baku, bentuk sampai pada ukuran mainan. Mainan yang dianggap aman untuk anak-anak saat ini adalah mainan-mainan yang terbuat dari bahan tekstil. Berbeda dari mainan berbahan kayu dan plastik, mainan dengan bahan tekstil memiliki sifat yang lunak dan empuk sehingga aman dan nyaman saat dimainkan oleh anak-anak, selain itu bahan tekstil memiliki tekstur yang sangat beragam yang dapat membantu melatih motorik halus anak. 
Teknik rajut dapat menghasilkan tekstur yang lembut hingga pada tekstur yang kasar dan bergelombang. Tekstur yang terbentuk pada kain yang dibuat dengan teknik rajut akan sangat membantu perkembangan motorik halus anak. Teknik rajut yang digunakan memberikan tesktur yang berbeda dan unik yang dapat membantu anak dalam belajar mengenal tekstur dan membantu mengasah motorik halus anak (Farikha et al., 2015). Seni merajut merupakan seni yang telah ada sejak lama dan berkembang di berbagai daerah di dunia. Terdapat dua teknik dalam merajut yaitu merenda yang umum dikenal dengan istilah crochet dan yang kedua adalah merajut atau knitting. Perbedaannya terletak pada alat dan teknik yang digunakan. Crochet menggunakan satu jarum yang disebut dengan hakpen, sementara knitting menggunakan dua jarum dan menghasilakan produk rajutan yang lebih rapat (Pang, 2016). Berbagai macam produk rajutan yang berkembang, beberapa tahun ini populer produk rajutan berupa boneka dengan bentuk yang lucu. Produk boneka rajut tersebut dirajut menggunakan teknik amigurumi.

Amigurumi, yang telah tersebar luas dalam beberapa tahun terakhir, merupakan teknik yang cocok untuk membuat souvenir dengan karakteristik budaya. Kata amigurumi dalam bahasa Jepang berasal dari kata "ami" (rajutan) dan "nuigurimi" (boneka). Kata tersebut dapat diterjemahkan sebagai "mainan yang terbuat dari rajutan". Amigurumi dikenal berasal dari Jepang, meskipun ada juga pendapat bahwa teknik ini ada di Cina sebelum Jepang. Sampel amigurumi pertama kali terlihat di Jepang pada awal 1970-an. Oleh karena itu, amigurumi juga dikenal sebagai "seni merajut Jepang”. Pada sekitar tahun 2000-an, amigurumi menyebar ke Amerika Serikat dan kemudian terus menyebar ke berbagai negara di dunia (ÇETIN, 2018). Ciri amigurumi antara lain: (a) memiliki bentuk yang imut, jika dalam budaya Jepang dikenal istilah 'kawaii' yang artinya imut atau lucu; (b) terdiri dari bentuk rajutan sederhana; (c) bagiannya terdiri dari kepala bundar, tubuh lonjong, kaki yang berbentuk tabung, seringkali proporsi kepala lebih besar daripada badan untuk menonjolkan kesan imut, dan (d) bagian dalamnya berisi dakron sehingga empuk (Rimoli, 2008). Kesederhanaan bentuk dan tampilannya yang imut dapat mudah disukai oleh anak-anak.

Terdapat berbagai jenis benang yang dapat digunakan dalam membuat rajutan. Sebelum menentukan jenis benang yang akan digunakan, dilakukan eksplorasi benang. Jenis benang yang digunakan dalam percobaan yaitu benang wool, benang polyester, dan benang katun. Masing-masing dari benang tersebut memiliki karakteristik yang berbeda. Percobaan ini dilakukan dengan membuat beberapa rajutan dengan teknik dasar untuk mengetahui karakteristik yang sesuai untuk mainan edukatif amigurumi bagi anak usia dini. Berdasarkan percobaan tersebut, hasilnya sebagai berikut:

- Benang wool memiliki karakteristik lentur dan lembut namun berserat serta kurang kuat

- Benang polyester memiliki karakteristik kuat, namun teksturnya keras dan kaku,

- Benang katun lebih kuat dibandingkan benang wool namun tidak sekuat benang polyester, memiliki tekstur lembut dan tidak berserat.

Benang katun dirasa paling cocok digunakan dalam mainan edukatif ini sebab memiliki tekstur yang paling sesuai bagi anak-anak. Meskipun benang wool bertekstur lembut, namun serat-seratnya akan menimbulkan ketidaknyamanan pada saat pemakaian serta kekuatannya tidak sebaik benang katun. Sementara itu, benang polyester yang lebih kuat dibandingkan benang katun memiliki kelemahan pada teksturnya yang kaku dan keras sehingga akan tidak nyaman untuk digunakan sebagai mainan. Benang katun yang digunakan adalah benang katun bali big ply, yaitu benang katun dengan helaian lebih besar dibandingkan katun biasanya. Katun bali memiliki karakteristik warna yang lebih mengkilap dibandingkan katun biasa. 
Sementara itum warna yang digunakan dalam mainan edukatif amigurumi ini adalah warna primer yang cerah selain untuk pengenalan warna dasar pada anak, warna primer juga memiliki kecerahan warna yang menarik bagi anak-anak. Selain benang, terdapat alat dan bahan lain yang digunakan dalam proses pembuatan amigurumi, yaitu:

- Hakpen ukuran 3/0, 4/0, 5/0, dan 6/0. Perbedaan ukuran hakpen menentukan tingkat kerapatan rajutan.

- Mata boneka

- Dakron untuk mengisi bagian dalam boneka agar empuk.

- Stitch marker atau penanda untuk mempermudah proses penghitungan jahitan (stitch).

- Jarum dan benang jahit.

Teknik dalam merajut juga berpengaruh pada tekstur permukaan dan hasil yang diinginkan. Teknik rajut yang digunakan pada penciptaan amigurumi ini dimaksudkan untuk memberikan rasa nyaman dan juga melatih indera peraba anak saat memainkannya. Crochet adalah bahasa perancis dari hook yang digunakan untuk membuat kaitan antar benang. Kait atau yang biasa disebut dengan hook/hakpen ini bisa terbuat dari kayu, besi, tulang ataupun plastik. Sedangkan knitting adalah jenis kerajinan yang berasal dari zaman Mesir kuno. Knitting adalah proses saling mengisi antara satu sengkelit dari benang satu ke benang lainnya menggunakan dua jarum songket (Farikha et al., 2015). Teknik dalam crochet antara lain: (1) tusuk awal untuk mengawali rajutan, (2) tusuk rantai sebagai dasar rajutan, (3) tusuk tunggal, (4) tusuk setengah ganda, (5) tusuk ganda, (6) tusuk triple, dan (7) tusuk sisip untuk menyambung dan membuat tusukan baru (Pang, 2007). Tusuk tunggal memiliki permukaan dengan tekstur yang lebih kecil jika dibandingkan dengan tusuk ganda. Dalam pembuatan amigurumi ini, tusuk tunggal digunakan pada bagian tubuh untuk menghasilkan kerapatan agar dakron tidak keluar dari rajutan. Kombinasi antara tusuk tunggal, tusuk setengah ganda, dan tusuk ganda digunakan pada bagian pakaian dan aksesoris amigurumi untuk menciptakan variasi bentuk dan tekstur.

\section{Analisis Mainan Edukatif Amigurumi Rama dan Sinta}

Mainan bisa dikategorikan sebagai mainan edukatif jika (a) diperuntukkan bagi anak balita; (b) multifungsi, yakni dari satu mainan bisa didapat berbagai variasi mainan sehingga stimulasi yang didapat anak juga lebih beragam (c) melatih problem solving; (d) melatih konsep-konsep dasar. Melalui permainan edukasi anak dilatih untuk mengembangkan kemampuan dasarnya seperti mengenal bentuk, warna, besaran, juga melatih motorik halus; (e) melatih ketelitian dan ketekunan; (f) merangsang kreativitas. Permainan edukatif mengajak anak untuk terus selalu kreatif melalui berbagai variasi mainan yang dilakukan (Pramono, 2012). Tiap anak memiliki gaya belajar yang sesuai untuk mengembangkan kemampuan menerima informasi, yang secara umum terdapat tiga macam gaya belajar yaitu visual, auditori, dan kinestetik (Suprayadi, 2021). Anak dengan tipe gaya belajar visual akan lebih mudah memahami informasi dengan cara melihat sehingga lebih peka terhadap warna, garis, dan bentuk, anak dengan gaya belajar auditori lebih mudah memahami menggunakan pendengaran, sementara anak dengan gaya belajar kinestetik lebih mudah belajar dengan melibatkan gerakan.

Objek yang dipilih sebagai desain produk kerajinan amigurumi adalah Rama dan Sinta dengan visualisasi gaya Kamasan. Terdapat tanda-tanda visual yang mencirikan karakter dari kedua tokoh tersebut yang dapat dilihat dari pakaian dan atributnya. Penggunaan warna pada lukisan Kamasan umumnya menggunakan warna-warna primer sehingga dalam perwujudan amigurumi juga akan digunakan kombinasi warna merah, 
kuning, dan biru untuk pakaian, dan krem untuk warna kulit. Tokoh Rama memiliki karakter wayang manis, yaitu kepribadian yang baik atau protagonis dan memiliki tingkah laku yang halus. Tokoh Rama dalam amigurumi akan menggunakan mahkota dan menggunakan celana panjang agar lebih nampak karakter raja dan gagah. Sementara itu, tokoh Sinta divisualisasikan memiliki rambut panjang, mengenakan mahkota, kain, dan atribut lain yang merujuk pada ciri visual lukisan Kamasan. Pada proses transformasi ini, bentuk karakter dibuat lebih sederhana dan dirancang agar tampak imut. Penyederhanaan tampak pada motif pakaian dan atribut-atributnya. Setelah desain amigurumi tersebut jadi, tahap selanjutnya adalah merajut bagian tubuh yang berawal dari bagian kaki ke bagian kepala. Di sela-sela proses merajut ini, dakron dimasukkan secara bertahap. Pada saat rajutan sampai pada letak mata, dilakukan pemasangan mata boneka, kemudian proses merajut dilanjutkan sampai bagian kepala selesai. Setelah bagian tubuh selesai, kemudian bagian rambut, pakaian, dan atribut dirajut satu persatu. Lalu, bagian-bagian tersebut dipasang menggunakan jarum dan benang jahit. Ukuran tinggi dari amigurumi Rama adalah $45 \mathrm{~cm}$ dan tinggu amigurumi Sinta adalah $40 \mathrm{~cm}$.

Berikut hasil perwujudan mainan edukatif amigurumi Rama dan Sinta berdasarkan referensi visual lukisan gaya Kamasan.

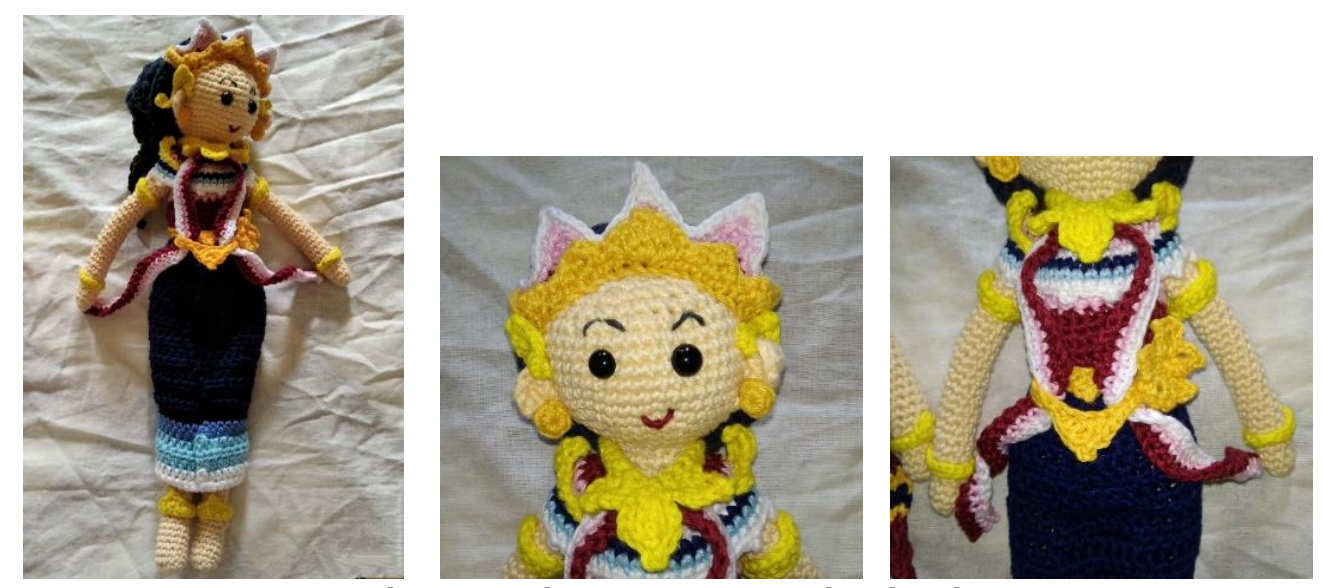

Gambar 1. Hasil amigurumi Sinta dan detailnya

(Sumber: dokumentasi pribadi)
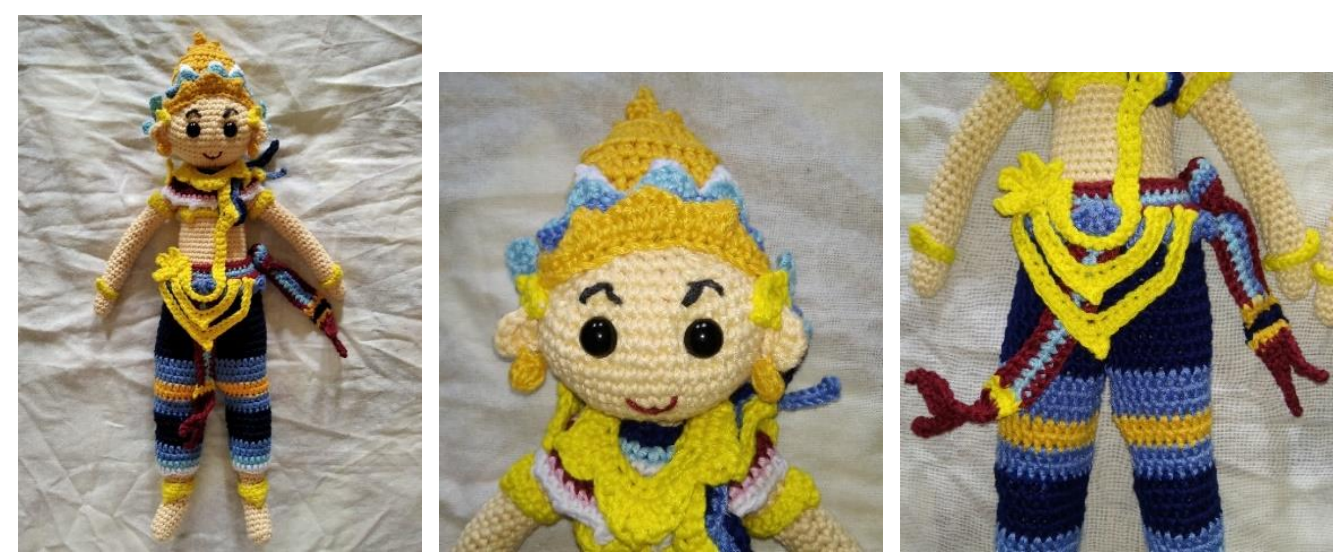

Gambar 2. Hasil amigurumi Rama dan detailnya

(Sumber: dokumentasi pribadi)

Hasil perwujudan mainan edukatif amigurumi tersebut bertujuan untuk dimanfaatkan sebagai sarana pendidikan karakter. Berikut analisis hasil perwujudan berdasarkan beberapa aspek, yaitu aspek fungsi, bahan, estetik, teknik, dan ergonomis: 
- Aspek fungsi: Secara konsep perancangan ini adalah membuat mainan edukatif yang dapat digunakan sebagai salah satu media bermain dan belajar untuk anak-anak usia dini. Perancangan ini digunakan sebagai pemenuhan kebutuhan permainan edukasi anak yang bermanfaat bagi proses pengembangan kreativitas anak. Produk ini dapat digunakan sebagai boneka untuk bermain anak, melatih komunikasi, interaksi, dan bermain peran. Produk ini juga dapat dimanfaatkan oleh guru/pendidik untuk menjadi sarana dalam metode ceramah agar tidak membosankan. Ceramah merupakan penyajian informasi secara lisan, dengan rentang waktu 5 sampai 45 menit, berbentuk informatif, penyampaian informasi secara detail dan terurai. Penyampaian secara lisan tersebut kerap membosankan bagi anak, maka diperlukan sarana untuk menarik perhatian dan mendorong keaktifan anak.

- Aspek bahan: Bahan merupakan hal terpenting yang dibutuhkan untuk terealisasinya karya, maka dipilih bahan yang sesuai dengan kosep. Bahan baku pada pembuatan produk ini adalah benang rajut katun bali big ply yang memiliki karakteristik warna cerah dan agak mengkipal, tekstur lembut, serta relatif kokoh sehingga nyaman saat disentuh dan awet. Pilihan warna dari katun bali sangat beragam. Warna benang yang dipilih adalah warna-warna primer dan warna cerah sehingga menarik bagi anakanak.

- Aspek estetik: Warna yang digunakan adalah warna-warna cerah sesuai sasaran anakanak usia dini seperti warna merah, kuning dan biru. Warna-warna cerah dipilih dengan pertimbangan dapat membangun suasana ceria, selain itu warna-warna cerah dapat merangsang kecerdasan dan kreativitas anak. Rancangan bentuk dari mainan edukatif ini divisualkan lebih sederhana dibandingkan dengan versi lukisan Kamasan yang detail dan rumit, namun tetap memiliki atribut-atribut kunci yang mencirikan Rama dan Sinta. Wajah dan anatomi tubuh yang sederhana menjadi menarik sebab memberikan kesan imut atau lucu dan dengan warna-warna cerah menjadi terlihat menyenangkan dan tidak monoton. Bentuk amigurumi tersebut juga dapat melatih literasi visual anak untuk lebih tertarik dan mengenal budaya lokal.

- Aspek teknik: Teknik yang digunakan dalam pembuatan produk ini adalah teknik rajut crochet. Crochet dipilih dengan tujuan membuat tekstur pada permukaan mainan dan memiliki fleksibilitas bentuk yang sesuai. Teknik crochet yang beragam dapat menghasilkan banyak tekstur yang berbeda seperti tusuk tunggal untuk menghasilkan tekstur yang lembut dan tusuk ganda menghasilkan tekstur permukaan kain yang bergelombang dan terlihat seperti memiliki motif bergaris pada permukaan kain.

- Aspek ergonomis: Tingkat ergonomik dari bahan rajutan yang digunakan dapat dibilang aman karena bahan berasal dari serat alam yaitu katun. Bahan ini juga nyaman karena karakternya lembut, meskipun memiliki tekstur yang tidak rata namun karena bahan yang digunakan adalah benang katun maka kain memiliki permukaan yang lembut saat tersentuh oleh kulit. Ukurannya juga memudahkan untuk dipegang/digenggam.

\section{SIMPULAN}

Pendidikan karakter seharusnya diberikan pada anak sejak sedini mungkin. Pendidikan karakter penting untuk membangun pengetahuan yang baik, perasaan yang baik, dan perilaku yang baik sehingga mewujudkan kesatuan perilaku dan sikap hidup peserta didik. Di dalamnya terdapat pewarisan nilai-nilai budaya yang luhur, dengan harapan dapat berpegang teguh pada prinsip-prinsip moral dalam hidupnya dan mempunyai keberanian melakukan yang benar, meskipun dihadapkan pada berbagai tantangan. Pendidikan karakter untuk anak usia dini sebaiknya dibuat semenarik 
mungkin agar tidak membosankan, untuk itu dibutuhkan suatu sarana seperti mainan edukatif. Namun, mainan edukatif sebagian besar menggunakan referensi budaya visual global. Masih belum banyak ditemukan mainan edukatif yang idenya bersumber dari budaya lokal, misalnya lukisan gaya Kamasan yang memiliki nilai budaya dan nilai sejarah yang tinggi. Dari sanalah ide penciptaan amigurumi dengan sumber visual gaya Kamasan ini muncul. Karakter Rama dan Sinta dalam epos Ramayana kerap dimunculkan dalam adegan-adegan lukisan gaya Kamasan. Kedua tokoh tersebut memiliki karakter protagonis, memiliki sifat yang setia, baik hati, welas asih, dan cerdas. Dengan pertimbangan tersebut, tokoh Rama dan Sinta dirasa sesuai untuk menjadi sumber ide penciptaan mainan edukatif. Agar sesuai dengan selera anak-anak, maka ide visual tersebut ditransformasikan dalam seni kriya rajut dengan teknik amigurumi berbahan benang katun bali yang bertekstur lembut dan kuat. Secara konsep perancangan ini adalah membuat mainan edukatif yang dapat digunakan sebagai salah satu media bermain dan belajar untuk anak-anak usia dini yang memiliki ciri budaya lokal. Secara fungsional, amigurumi Rama dan Sinta ini dapat digunakan sebagai boneka untuk bermain anak, melatih komunikasi, interaksi, dan bermain peran. Selain itu juga dapat dimanfaatkan oleh guru/pendidik untuk menjadi sarana penguatan pendidikan karakter secara lebih efektif sehingga anak-anak dapat belajar mengenai baik dan buruk serta memahami dampak dari perbuatan tersebut.

\section{DAFTAR PUSTAKA}

Budiana, I. K., \& Parta, I. W. S. (2015). Seni Rupa Bali sebagai Aset Pusaka Budaya (I. W. S. Parta (ed.)). Pemerintah Kabupaten Gianyar \& Dinas Kebudayaan Kabupaten Gianyar.

Djatiprambudi, D. (2019). Reinvensi Budaya Visual Nusantara sebagai Basis Penciptaan Seni Rupa (Kontemporer). Seminar Nasional Seni Dan Desain 2019, September, 9-18.

Farikha, A. Y., Widiastuti, T., \& Affanti, T. B. (2015). MAINAN ANAK BERBAHAN TEKSTIL MENGGUNAKAN TEKNIK RAJUT DENGAN IDE MAINAN BALOK SUSUN. Texfile, II(1), 1-13.

Hidajat, R., Pujiyanto, Hartono, \& Hasyimy, M. 'Afaf. (2021). Aesthetical Transformation on Ramayana Stories of Indonesia- Thailand Versions. Proceedings of the 5th International Conference on Arts Language and Culture (ICALC 2020), 534(534), 177-184. https://doi.org/10.2991/assehr.k.210226.063

Iswantiningtyas, V., \& Wulansari, W. (2018). Pentingnya Penilaian Pendidikan Karakter Anak Usia Dini. Proceedings of the ICECRS, 1(3), 197-204. https://doi.org/10.21070/picecrs.v1i3.1396

Kemendiknas. (2011). Panduan Pelaksanaan Pendidikan Karakter. In Badan Penelitian dan Pengembangan Pusat Kurikulum dan Perbukuan.

Lathifah, Z. (2020). Literasi Visual untuk Peningkatan Kecerdasan Membaca di Era Industri 4.0. Educivila: $\begin{array}{lllll}\text { Jurnal Pengabdian } & \text { Mada } & \text { 49-57. }\end{array}$ http://library1.nida.ac.th/termpaper6/sd/2554/19755.pdf

Muchtar, D., \& Suryani, A. (2019). Pendidikan Karakter Menurut Kemendikbud. Edumaspul: Jurnal Pendidikan, 3(2), 50-57. https://doi.org/10.33487/edumaspul.v3i2.142

Mudana, I. G. A. M. G. (2019). Membangun Karakter Dalam Perspektif Filsafat Pendidikan Ki Hadjar Dewantara. Jurnal Filsafat Indonesia, 2(2), 75. https://doi.org/10.23887/jfi.v2i2.21285

Pang, T. (2007). Rajutan Untuk Pemula. Jakarta: Puspa Swara.

Parta, I. W. S. (2011). Perkembangan Seni Rupa Pita Maha dalam Konteks Konstruksi Seni Rupa Bali. Mudra, 26(2),

181-192.

https://www.google.com/url?sa=t\&rct=j\&q=\&esrc=s\&source=web\&cd=\&cad=rja\&uact=8\&ved=2ahU KEwiu7dXnms_sAhXp73MBHaWACBcQFjAAegQIARAC\&url=http\%3A\%2F\%2Frepo.isidps.ac.id\%2F1687\%2F1\%2F948-3445-1-PB.pdf\&usg=AOvVaw3jjF4aDN-tYwyxjKiEmwgr

Pramono, S. (2012). Permainan Asyik Bikin Anak Pintar. Yogyakarta: IN AzNa Books.

Pujiyanto, Hidajat, R., Anggriani, S. D., Aini, N., \& Shaari, N. (2021). The Creativity of Designing Batik Serumpun Melayu Through Indonesian-Malaysian Cultural Acculturation. Proceedings of the 5th International Conference on Arts Language and Culture (ICALC 2020), 534(534), 54-60. https://doi.org/10.2991/assehr.k.210226.047

Puspitasari, E. (2014). Pendekatan Pendidikan Karakter. Jurnal Edueksos, III(2), 45-57.

Rimoli, A. P. (2008). Amigurumi World: Seriously Cute Crochet. Woodinville, WA: Martingale.

Suprayadi, M. (2021). Menakar Bakat Minat Melalui Three Type Learning Methods. Jurnal Teknosains 
Kodepena, 1(2), 50-57.

Suwidiarta, I. K. (2017). Grosifikasi Ideologi Rasa Dalam Perkembangan Seni Lukis Bali. Dharmasmrti: Jurnal Ilmu Agama Dan Kebudayaan, 17(2), 20-29. https://doi.org/10.32795/ds.v17i02.85

Wantu, H. M. (2020). Pendidikan Karakter Untuk Membentuk Moralitas Anak Bangsa. Irfani, 16(1), 1-8. https://doi.org/10.30603/ir.v16i1.1310

Wigunadika, I. W. S. (2018). Pendidikan Karakter Berbasis Kearifan Lokal. Purwadita, 2(2), 91-100. https://doi.org/10.30868/ei.v5i10.6 